\title{
Mitochondrial Protein Import: Identification of Processing Peptidase and of PEP, a Processing Enhancing Protein
}

\author{
Gerhard Hawlitschek, Helmut Schneider, \\ Bernd Schmidt, Maximilian Tropschug, \\ Franz-Ulrich Hartl, and Walter Neupert \\ Institut für Physiologische Chemie, Physikalische \\ Biochemie und Zelibiologie \\ Universität München \\ Goethestrasse 33 \\ D-8000 Munich 2, Federal Republic of Germany
}

\section{Summary}

Transport of nuclear-encoded precursor proteins into mitochondria includes proteolytic cleavage of aminoterminal targeting sequences in the mitochondrial matrix. We have isolated the processing activity from Neurospora crassa. The final preparation (enriched ca. 10,000-fold over cell extracts) consists of two proteins, the matrix processing peptidase (MPP, $57 \mathrm{kd}$ ) and a processing enhancing protein (PEP, $52 \mathrm{kd}$ ). The two components were isolated as monomers. PEP is about 15-fold more abundant in mitochondria than MPP. It is partly associated with the inner membrane, while MPP is soluble in the matrix. MPP alone has a low processing activity whereas PEP alone has no apparent activity. Upon recombining both, full processing activity is restored. Our data indicate that MPP contains the catalytic site and that PEP has an enhancIng function. The mitochondrial processing enzyme appears to represent a new type of "signal peptidase," different from the bacterial leader peptidase and the signal peptidase of the endoplasmic reticulum.

Introduction

Most nuclear-encoded precursors of mitochondrial proteins contain amino-terminal presequences (for reviews see Pfanner and Neupert, 1987; Nicholson and Neupert, 1988). These presequences are required for the precursors to enter the mitochondrial matrix, where they are proteolytically removed (Hurt et al., 1984; Horwich et al., 1985, 1986; Emr et al., 1986; Keng et al., 1986; Grivell et al., 1987; Vassarotti et al., 1987a). This cleavage is not essential for completing import but is necessary for further assembly of the newly imported polypeptides into functional complexes (Zwizinski and Neupert, 1983; Lewin and Norman, 1983; Ou et al., 1986; Hartl et al., 1986, 1987). Precursor targeting sequences differ considerably in their structures. One of the few common themes is the high content of positively charged amino acids and of hydroxylated amino acids. Presequences may form amphipathic structure in the form of either $\alpha$-helices or $\beta$-sheets (von Heijne, 1986; Roise et al., 1986; Vassarotti et al., $1987 \mathrm{~b})$. Despite the large variability of the sequences of mitochondrial leader peptides, relatively minor alterations of the presequence can prevent cleavage by the processing peptidase (Hurt et al., 1987; Grivell, 1987; Nguyen et al., 1987). This suggests that distinct, but up to now undefined, structural elements are required for cleavage. Similarly, the cleavage sites show wide variation among different precursors of a single organism and among precursors of different organisms (for review see Nicholson and Neupert, 1988).

The enzyme responsible for the cleavage of presequences was initially found in the matrix of yeast mitochondria (Böhni et al,, 1980; McAda and Douglas, 1982) and later also in the mitochondrial matrix of other organisms (Miura et al., 1982; Conboy et al., 1982; Schmidt et al., 1984). This matrix protease, or processing peptidase, is a soluble protein in both mitochondria and the chloroplast stroma (Robinson and Ellis, 1984). It is different from the signal peptidase or leader peptidase that cleaves off the amino-terminal signal sequences from proteins being translocated across the membranes of the endoplasmic reticulum (Evans et al., 1986) or across the plasma membrane of bacteria (Zwizinski and Wickner, 1980; Dev and Ray, 1984), respectively. The processing peptidase from mitochondria (and from chloroplasts) is dependent on divalent metal ions such as $\mathrm{Mn}^{2+}, \mathrm{Zn}^{2+}$, or $\mathrm{Co}^{2+}$ and is inhibited by metal chelators such as EDTA and orthophenanthroline or bathophenanthroline. It is therefore assumed that the enzyme is a metalloprotease.

The processing peptidase has been partially purified from different sources (McAda and Douglas, 1982; Böhni et al., 1983; Kumamoto et al., 1986). Molecular characterization of the pure enzyme, however, is required to answer a number of questions concerning mitochondrial biogenesis: is there only a single enzyme for the hundreds of different precursor proteins? If so, how can it recognize the extreme variety of presequences and cleavage sites? Does the enzyme perform only a single peptide-bond cleavage during removal of the signal peptide? What is its evolutionary relationship to other peptidases? How is the peptidase itself synthesized and processed in the course of its import?

Here we describe the purification of the processing enzyme, starting with whole-cell extracts from Neurospora crassa. Two ditferent proteins were found to be required for full enzyme activity, namely the processing peptidase (MPP, $57 \mathrm{kd}$ ) and a processing enhancing protein (PEP, 52 kd). They did not form a detectable complex. MPP and PEP were readily resolved with most chromatographic procedures applied. This appears to explain the low yields of processing activity during purification and the difficulty in purifying the enzyme. Upon mixing both polypeptides, activity was restored. The MPP component appears to bear the catalytic activity, which is stimulated by PEP. The two proteins are present in unequal molar amounts, PEP being about 15 -fold more abundant. In contrast to the MPP polypeptide, which is completely soluble in the matrix, PEP is partly associated with the inner surface of the inner membrane. We suggest that the two proteins cooperate in binding precursors and proteolytic cleavage. The cDNA sequence of PEP is also reported. 


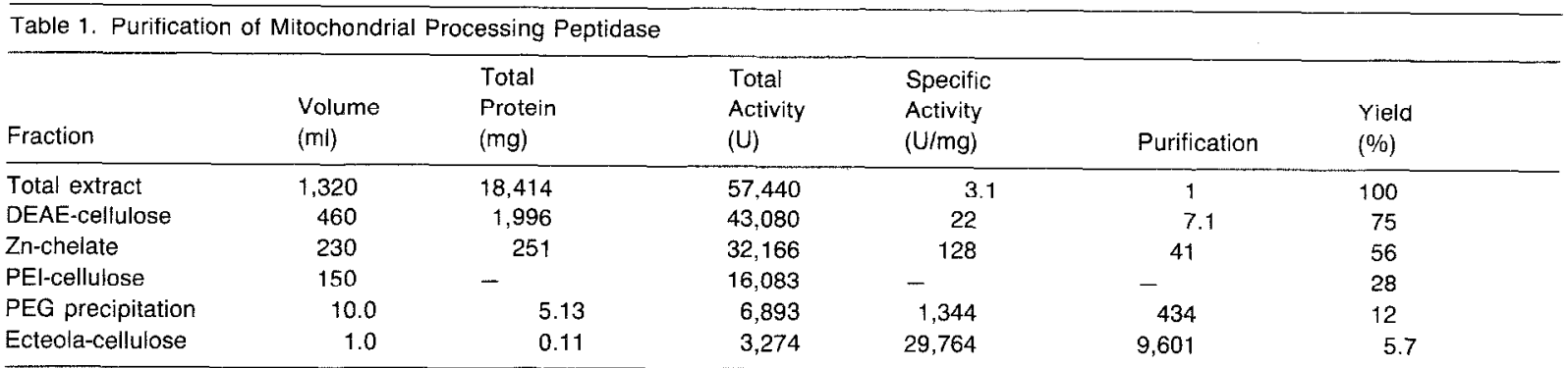

The processing peptidase of Neurospora mitochondria was isolated by subjecting a total cell extract to the purification steps indicated (see Experimental Procedures). One unit of activity was defined as that amount of enzyme catalyzing the cleavage of 1 fmol of precursor per min at $25^{\circ} \mathrm{C}$. For each fraction obtained, total volume, protein content, and activity were measured, and specific activities, purification factors, and yields were calculated. Because of interference of PEI with the protein assay, we were unable to determine the protein content of the fraction obtained after PEI-cellulose chromatography.

\section{Results}

\section{Purification of Processing Enzyme}

Table 1 summarizes the purification of the processing activity from a Neurospora cell extract. The activity was tested with precursors of subunit 2 and subunit 9 of ATP synthase. We define $1 \mathrm{U}$ of activity as that amount of enzyme which cleaves $1 \mathrm{fmol}$ of precursor per $\min$ at $25^{\circ} \mathrm{C}$. The cell extract was subjected sequentially to DEAEcellulose chromatography, Zn-chelate chromatography, and polyethyleneimine (PEI)-cellulose chromatography. After precipitation of the activity with polyethylene glycol (PEG), a final chromatographic step was performed on Ecteola-cellulose. The purification was about 10,000-fold and the final yield was ca. $6 \%$. The various purification steps were monitored by SDS-polyacrylamide gel electrophoresis and staining of protein bands with Coomassie blue (Figure 1). The final preparation consisted of two polypeptides, with apparent molecular weights of 57,000 and 52,000 . As revealed by densitometry, the $52 \mathrm{kd}$ polypeptide was in ca. 1.6-fold excess over the $57 \mathrm{kd}$ component.

The $\mathbf{5 7} \mathbf{k d}$ and $\mathbf{5 2}$ kd Proteins Are Associated with Processing Activity but Do Not Form a Complex

The enzyme preparation obtained after $\mathrm{Zn}$-chelate chromatography was subjected to FPLC gel filtration on Superose 12. Later steps were not suitable for molecular sieving since the presence of detergent considerably changed the behavior of the $57 \mathrm{kd}$ and $52 \mathrm{kd}$ polypeptides on such a column. Gel electrophoresis and immunoblotting (see below) of the FPLC fractions revealed a partial separation of the $57 \mathrm{kd}$ and $52 \mathrm{kd}$ polypeptides. This demonstrates that they did not form a complex under the conditions of the gel filtration. Each protein migrated at its apparent monomeric molecular weight (Figure 2A). This was observed at low $(50 \mathrm{mM} \mathrm{NaCl})$ and at high $(300 \mathrm{mM}$ $\mathrm{NaCl}$ ) salt concentrations. When the enzymatic activity of the various fractions was measured, the peak catalytic activity did not coincide with either protein peak (Figure 2B, panel a). Moreover, the yield of activity over the whole gradient was only $10 \%$. This suggests that both the $57 \mathrm{kd}$ and

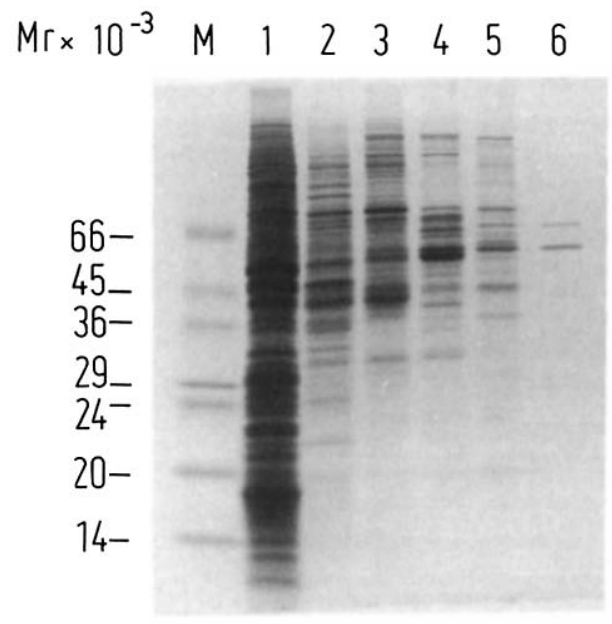

Figure 1. Purification of Mitochondrial Processing Enzyme: SDSPolyacryiamide Gel Electrophoresis of Different Steps

Aliquots of different fractions of the processing enzyme purification were lyophilized. The residues were treated with $50 \%$ methanol, and precipitated protein was centrifuged, solubilized in SDS-containing buffer, and electrophoresed on a 16\% polyacrylanide gel. Proteins were stained with Coomassie blue R-250. Lane 1, total cell extract (350 $\mu \mathrm{g}$ ); lane 2, eluate of DEAE-cellulose chromatography $(32 \mu \mathrm{g})$; lane 3 eluate of $\mathrm{Zn}$-chelate chromatography $(38 \mu \mathrm{g})$; lane 4 , eluate of $\mathrm{PEI}$ cellulose chromatography $(30 \mu \mathrm{g})$; lane 5 , pellet of PEG precipitation $(25 \mu \mathrm{g})$; lane 6, eluate of Ecteola-cellulose chromatography $(3 \mu \mathrm{g})$

52 kd polypeptides are necessary for full activity. To test whether two essential factors were being resolved, selected fractions obtained by FPLC gel filtration were mixed and enzyme activity was determined (Figure 2B). Fractions 8-10, which contained 52 kd polypeptide but little or no $57 \mathrm{kd}$ polypeptide, were able to stimulate activity in fractions 4-6, which contained the $57 \mathrm{kd}$ polypeptide (Figure $2 \mathrm{~B}$, panels $\mathrm{b}-\mathrm{d}$ ). Likewise, when fractions 4 or 5 , containing mainly $57 \mathrm{kd}$ polypeptide, were added to the various gradient fractions, high enzyme activities were found in $52 \mathrm{kd}$ polypeptide-containing fractions 8-10 (not shown). We conclude from these data that both the $57 \mathrm{kd}$ and the $52 \mathrm{kd}$ polypeptides are required for enzyme activity, although they are apparently not present in a complex. 
A

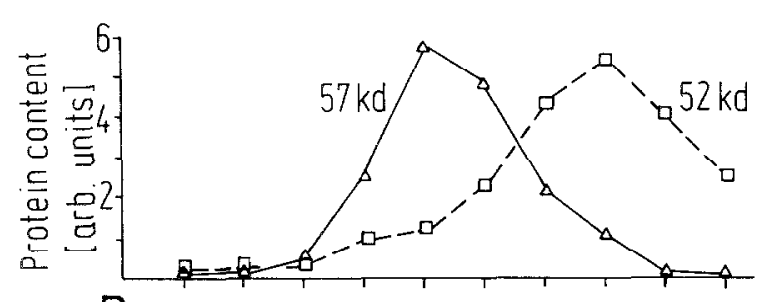

B

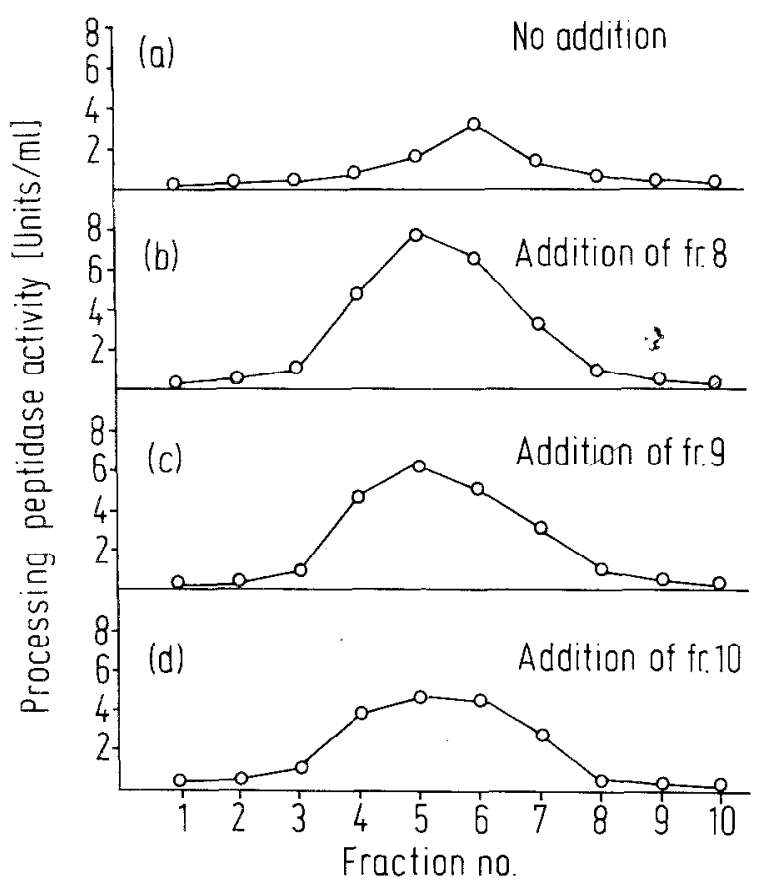

Figure 2. Gel Chromatography of the Eluate of $\mathrm{Zn}$-Chelate Chromatography

Five hundred microliters of the eluate of Zn-chelate chromatography was chromatographed on a Superose 12 column as described in Experimental Procedures. Fractions of $250 \mu \mathrm{l}$ were collected.

(A) Aliquots of each fraction were precipitated with trichloroacetic acid (TCA) and analyzed by SDS-polyacrylamide gel electrophoresis and Western blotting. The elution profiles of the $52 \mathrm{kd}$ and $57 \mathrm{kd}$ proteins were determined by immunostaining with antisera directed against both proteins using $\left[{ }^{14} \mathrm{C}\right]$ protein $\mathrm{A}$ as a label and autoradiography. Quantification was carried out by laser densitometry.

(B) Ten microliters of each fraction was tested for processing peptidase activity as described in Experimental Procedures. (a) shows the elution profile of the processing activity without any addition of other fractions. In (b-d), $10 \mu$ l of fraction 8 (b), fraction 9 (c), or fraction 10 (d) was included in the assay.

\section{The $\mathbf{5 2}$ kd Component Is about 15-Fold More Abundant in Mitochondria Than the $\mathbf{5 7} \mathrm{kd}$ Component}

We prepared antibodies against the $57 \mathrm{kd}$ and the $52 \mathrm{kd}$ polypeptides by blotting the final preparation after gel electrophoresis to nitrocellulose and by immunizing rabbits with the individual bands cut from the nitrocellulose paper. The specificities of the antibodies obtained are demonstrated in Figures $3 \mathrm{~A}$ and 3B. On a Western blot of a total extract from Neurospora mitochondria, the $57 \mathrm{kd}$ antibody recognized only the $57 \mathrm{kd}$ protein, and the $52 \mathrm{kd}$
A

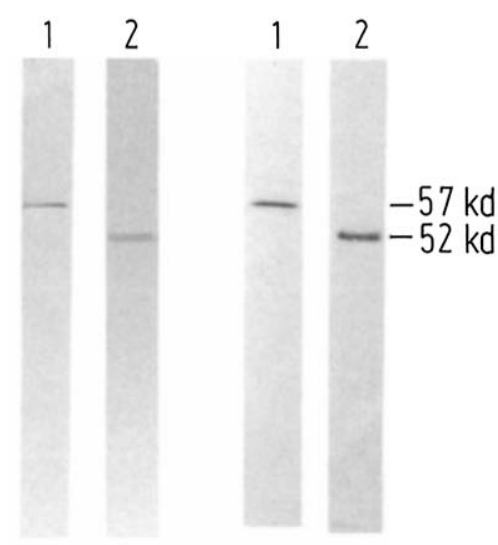

Figure 3. Immunoprecipitation and Immunoblotting of the $57 \mathrm{kd}$ and 52 kd Polypeptides from a Mitochondrial Extract

(A) Mitochondrial pellets $(100 \mathrm{ug})$ were solubilized in $30 \mathrm{mM}$ Tris- $\mathrm{HCl}$ (pH 8.2), $300 \mathrm{mM} \mathrm{NaCl}, 1 \%$ Triton X-100. The extracts were electrophoresed on a $12.5 \%$ polyacrylamide-SDS gel and electrotransferred to nitrocellulose paper (Burnette, 1981). Immunolabeling was done with antisera against the $57 \mathrm{kd}$ polypeptide (lane 1) and against the $52 \mathrm{kd}$ polypeptide (lane 2). Bound antibodies were visualized by decoration with $\left[{ }^{14} \mathrm{C}\right]$ protein $\mathrm{A}$ and autoradiography.

(B) Mitochondria were isolated from Neurospora cells grown in the presence of [ $\left.{ }^{35} \mathrm{~S}\right]$ sulfate, and mitochondrial extracts were prepared as in (A). The $57 \mathrm{kd}$ component (lane 1) and $52 \mathrm{kd}$ component (lane 2) were immunoprecipitated from extracts corresponding to $100 \mu \mathrm{g}$ and $5 \mu \mathrm{g}$ of mitochondria, respectively. Precipitates were dissociated in SDS-containing buffer and analyzed by electrophoresis and fluorography.

antibody recognized only the $52 \mathrm{kd}$ protein (Figure $3 \mathrm{~A}$ ). Furthermore, direct immunoprecipitation from mitochondrial extracts led to selective precipitation of the $57 \mathrm{kd}$ and $52 \mathrm{kd}$ polypeptides (Figure $3 \mathrm{~B}$ ).

To determine quantitatively the amounts of $57 \mathrm{kd}$ protein and $52 \mathrm{kd}$ protein in mitochondria, we performed immunotitration employing mitochondria from Neurospora cells grown in the presence of [ ${ }^{35}$ S $]$ sulfate or [ $\left.{ }^{3} \mathrm{H}\right]$ leucine. As judged from radioactivity in the immunoprecipitate, the $57 \mathrm{kd}$ polypeptide is $0.03 \%$ of total mitochondrial protein, whereas the $52 \mathrm{kd}$ protein is $0.4 \%-0.45 \%$. Thus the $52 \mathrm{kd}$ component is roughly 15 times more abundant than the $57 \mathrm{kd}$ polypeptide. The relative content of $57 \mathrm{kd}$ polypep tide in mitochondria of $0.03 \%$ corresponds to a relative content in whole cells of about $0.006 \%$. This compares well with the purification factor of the final preparation of the processing enzyme (see Table 1). The relative cellular contents of the $57 \mathrm{kd}$ and $52 \mathrm{kd}$ polypeptides, as measured by immunoprecipitation, were found to agree with the relative frequencies of cDNA clones for the two polypeptides in a Neurospora cDNA library (Tropschug and Neupert, unpublished). Based on the content of $57 \mathrm{kd}$ and $52 \mathrm{kd}$ polypeptides in the total mitochondrial extract and their relative proportions in the purified preparation, the final yields of $57 \mathrm{kd}$ and $52 \mathrm{kd}$ polypeptides are $4 \%$ and $0.5 \%$, respectively. 


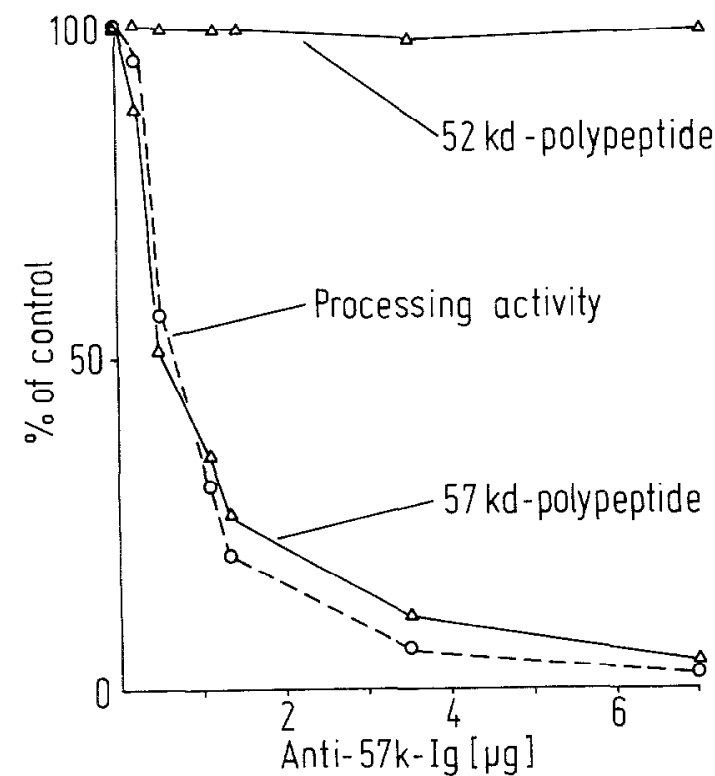

Figure 4. Removal of the $57 \mathrm{kd}$ Component and of Processing Activity from a Mitochondrial Extract by Anti-57 kd Antibodies

Increasing amounts of immune globulins directed against the $57 \mathrm{kd}$ polypeptide together with decreasing amounts of preimmune globulins were prebound to protein A-Sepharose. The samples thus contained roughly the same amounts of bound globulins, and the control contained only preimmune globulins. Mitochondrial pellets $(20 \mu \mathrm{g})$ were lysed as in Figure 3 , and the $57 \mathrm{kd}$ component was immunoadsorbed to the Sepharose beads by end-over-end mixing at $4^{\circ} \mathrm{C}$ for $90 \mathrm{~min}$. The beads were collected by centrifugation, and one-half of the supernatant was tested for processing activity. The other half was TCA-precipitated, electrophoresed on a $16 \%$ polyacrylamide gel under nonreducing conditions, and electrotransferred to nitrocellulose paper. Immunodetection of the $57 \mathrm{kd}$ polypeptide was carried out as in Figure 3. Quantification was by laser densitometry. Activity (dashed line) and amounts of the proteins (solid lines) are expressed as percentages of the corresponding totals (control).

\section{The $\mathbf{5 7}$ kd Polypeptide Is Limiting for Processing Activity in Mitochondrial Extracts}

Antibodies were used to titrate the processing activity in mitochondrial extracts. Isolated mitochondria were lysed with Triton $\mathrm{X}-100$. Increasing amounts of anti- $57 \mathrm{kd}$ or anti$52 \mathrm{kd}$ antibodies prebound to protein A-Sepharose were added to aliquots of the extracts. After centrifugation, the supernatants were collected, and the $57 \mathrm{kd}$ and $52 \mathrm{kd}$ polypeptides and enzyme activity remaining in the supernatant were determined. As shown in Figure 4, the $57 \mathrm{kd}$ polypeptide and the enzyme activity were removed from the lysed mitochondria with the anti-57 kd antibody in a parallel manner, while the $52 \mathrm{kd}$ component stayed in the supernatant. Up to $50 \%$ of the $52 \mathrm{kd}$ polypeptide was removed from the lysed mitochondria by the anti- $52 \mathrm{kd}$ antibody, but this was not accompanied by a decrease in the enzyme activity (not shown). The effect of complete depletion of $52 \mathrm{kd}$ polypeptide from the mitochondrial extracts could not be measured in these experiments, since antibody amounts needed to achieve this led to unspecific inhibition of processing activity, an effect also observed with corresponding amounts of preimmune globulins. These data demonstrate that the $57 \mathrm{kd}$ and the $52 \mathrm{kd}$ polypep- tides are separate components in crude mitochondrial extracts and that the $57 \mathrm{kd}$ polypeptide is limiting for processing activity. The $52 \mathrm{kd}$ polypeptide is not limiting for activity, probably because it is present in higher molar amounts.

\section{Proteolytic Activity Is Associated with \\ the $\mathbf{5 7}$ kd Component}

When a Triton X-100 extract from mitochondria or a purfied preparation of the processing enzyme (not shown) was incubated with antibody against the $57 \mathrm{kd}$ component, the enzyme activity was not diminished. The same was true when preimmune serum was used (Figure 5A, columns 1 and 2). Apparently the antibodies bind to the $57 \mathrm{kd}$ polypeptide but do not thereby affect its enzymatic activity. Addition of protein A-Sepharose to samples treated with $57 \mathrm{kd}$ antibodies led to a $30 \%$ reduction in the enzyme activity, whereas no reduction was observed in the preimmune control (Figure 5A, columns 3 and 4). Binding of the $57 \mathrm{kd}$ polypeptide-antibody complex to protein A-Sepharose may interfere to a limited degree with the enzyme reaction. When the immune complex was removed from the sample by centrifugation, the supernatant was completely devoid of enzyme activity (Figure 5A, column 6), but the pellet containing the complex also had very little activity (ca. $5 \%$ of the total in the extract, column 8). When the pellet and supernatant were mixed again, however, processing activity was reconstituted to almost the original level (Figure 5A, column 9).

The experiment in which gel filtration fractions were mixed (Figure 2) indicated that the $52 \mathrm{kd}$ polypeptide in the supernatants was responsible for activation of the processing enzyme. To substantiate this result, we tested the effect of pure $52 \mathrm{kd}$ polypeptide on the activity of an immunoadsorbed $57 \mathrm{kd}$ component. The purified $52 \mathrm{kd}$ polypeptide led to the same activation as the supernatant fraction (Figure 5B).

The immunoadsorbed $57 \mathrm{kd}$ polypeptide had low but detectable enzyme activity by itself (Figure 5A, column 8). When a 20-fold higher amount of immunoadsorbed $57 \mathrm{kd}$ polypeptide was analyzed in the enzyme assay, the activity was about the same as that of the original sample (Figure $5 \mathrm{~A}$, column 10). To control whether this residual activity was due to $57 \mathrm{kd}$ polypeptide alone, we analyzed for possible contamination by $52 \mathrm{kd}$ polypeptide. Immunoblots showed that the anti-57 kd antibody precipitated all the $57 \mathrm{kd}$ polypeptide from mitochondrial extracts and that no $52 \mathrm{kd}$ polypeptide was detectable in the immunoprecipitate (Figure $5 \mathrm{C}$ ). Titration of the sensitivity of the immunoblot revealed that less than $0.5 \%$ of $52 \mathrm{kd}$ polypeptide initially present in the extract could have been detected. On the other hand, about $5 \%$ of the initial processing activity was left in the immunoprecipitate of the $57 \mathrm{kd}$ polypeptide (see Figure 5A). The same result was obtained when a preparation of the purified processing enzyme was used in the experiment instead of crude mitochondrial extracts. These data indicate that the $57 \mathrm{kd}$ polypeptide has a low intrinsic enzyme activity in the absence of $52 \mathrm{kd}$ polypeptide and that the latter has a strong stimulating influence on the processing activity. 
A

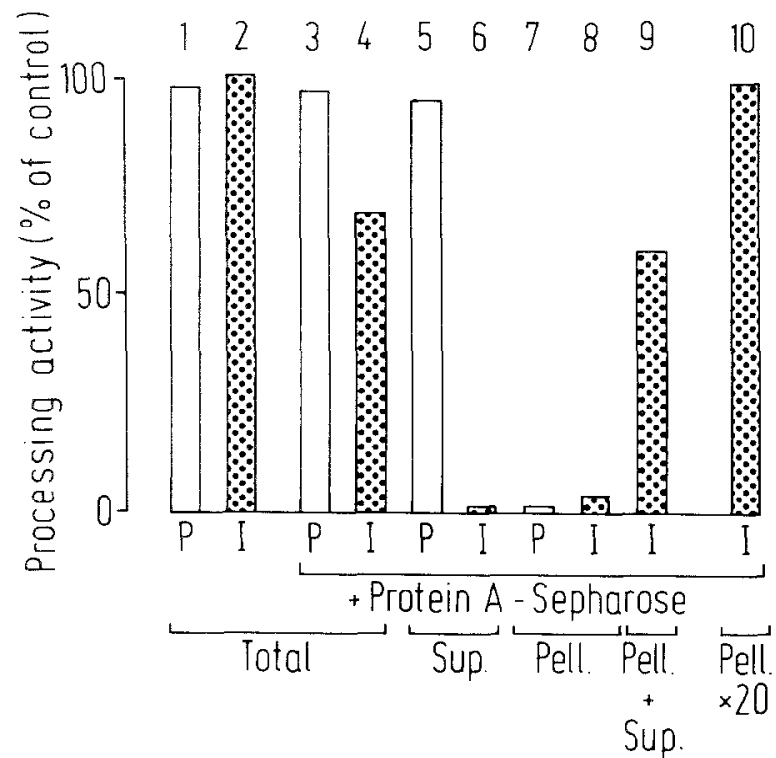

B 112230456
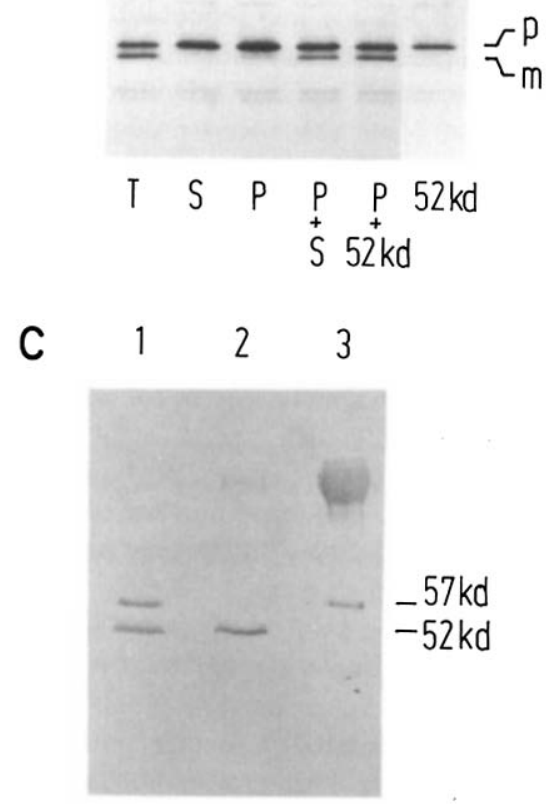

Figure 5. Reconstitution of the Processing Activity by the 52 kd Polypeptide after Isolation of the $57 \mathrm{kd}$ Polypeptide by Immunoadsorption (A) Mitochondrial pellets $(20 \mu \mathrm{g})$ were solubilized in a volume of 200 $\mu \mathrm{l}$ as in Figure $3 \mathrm{~A}$. Resulting extracts were incubated for $15 \mathrm{~min}$ at $4^{\circ} \mathrm{C}$ with either preimmune globulins or immune globulins directed against the $57 \mathrm{kd}$ polypeptide. Antigen-antibody complexes were then bound to protein A-Sepharosc, and the beads were sedimented by centrifugation. Supernatants were kept on ice, and peliets were washed three times with $30 \mathrm{mM}$ Tris- $\mathrm{HCl}(\mathrm{pH} 8.2), 300 \mathrm{mM} \mathrm{NaCl}, 1 \%$ Triton X-100, and resuspended in $200 \mu$ l of the same buffer. Aliquots corresponding to $1 \mu \mathrm{g}$ of untreated mitochondria were taken. Where indicated, supernatants and pellets were remixed and incubated for a further $10 \mathrm{~min}$. All fractions were tested for processing activity. Activilies are expressed as a percentage of the activity of the mitochondrial extract without addition of antibodies. Columns 1-4, activities in total fractions;

\section{Part of the $\mathbf{5 2}$ kd Polypeptide Is Attached to the Inner Mitochondrial Membrane}

Earlier studies localized the processing enzyme as a soluble activity in the mitochondrial matrix (e.g., by digitonin fractionation) (Schmidt et al., 1984). In the isolation procedure employed here, processing activity was extracted by a hypotonic buffer without addition of salt (see Experimental Procedures). On the other hand, we noted that the lower final yield of $52 \mathrm{kd}$ polypeptide, relative to $57 \mathrm{kd}$ polypeptide, was mainly due to losses during this extraction step. We theretore investigated whether the $52 \mathrm{kd}$ component might be partly associated with the inner membrane.

Isolated mitochondria were disrupted by sonication in the presence of increasing salt concentrations, and the release of $52 \mathrm{kd}$ and $57 \mathrm{kd}$ polypeptides into the soluble fraction was measured (Figure 6). At high $\mathrm{KCl}$ concentrations up to $85 \%$ of the $57 \mathrm{kd}$ polypeptide was extracted from mitochondria, as was the soluble matrix marker fumarase. In contrast, only $20 \%-30 \%$ of the total $52 \mathrm{kd}$ polypeptide was soluble in either the absence or presence of salt. The rest was membrane associated. The integral membrane marker ADPIATP-carrier was completely recovered in the membrane fraction. This is also known to be the case upon alkaline treatment of mitochondria (Pfanner et al., 1987b). The $52 \mathrm{kd}$ polypeptide, however, was completely extractable from the membranes at alkaline $\mathrm{pH}$ (not shown). These data indicate that about $75 \%$ of total $52 \mathrm{kd}$ polypeptide is attached to the surface of the inner membrane but in a manner that does not involve direct embedding of the polypeptide in the phospholipid bilayer.

Characteristics of the Purified Processing Enzyme The final enzyme preparation was analyzed for its catalytic requirement under various conditions. The enzyme

columns 5,6 and 7,8 , activities in supernatants and pellets, respectively; column 9, activity in pellet and supernatant after remixing; column 10 , activity in pellet, but corresponding to $20 \mu \mathrm{g}$ of mitochondria instead of $1 \mu \mathrm{g}$. P, incubation with preimmune globutins. I, incubation with anti-57 kd immune globulins.

(B) Mitochondrial extracts were prepared, and anti-57 kd antibody-protein A-Sepharose complex was added as in (A). Aliquots tested for processing activity corresponded to the extract obtained from $\uparrow \mu \mathrm{g}$ of mitochondria. Processing of the precursor of ATPase subunit 2 was analyzed. Lane 1, without further treatment $(T)$; lane 2, supernatant (S) after removal of immune complexes by centrifugation; lane 3 pellet (P) containing the $57 \mathrm{kd}$ polypeptide immunoadsorbed to protein A-Sepharose; lane 4, pellet and supernatant remixed; lane 5, pellet after addition of approximately $0.1 \mu \mathrm{g}$ of $52 \mathrm{kd}$ poiypeptide; lane $6,0.1$ $\mu \mathrm{g}$ of $52 \mathrm{kd}$ polypeptide alone. At right, the precursor $(\mathrm{p})$ and mature (m) forms of subunit 2 of $F_{0} F_{1}$-ATPase are indicated.

(C) The $57 \mathrm{kd}$ polypeptidc was immunoadsorbed to Sepharose beads as in (A) except that $200 \mu \mathrm{g}$ of mitochondria was used. One-half of the sample was directly precipitated with TCA. The other half was centrifuged to obtain a pelfet, containing the Sepharose beads, and a supernatant; pellet and supernatant were then TCA-precipitated. TCA precipitates were treated with SDS-containing buffer and subjected to electrophoresis. Proteins were blotted to nitrocellulose paper and decorated with antibodies against both $52 \mathrm{kd}$ and $57 \mathrm{kd}$ polypeptides. Bound antibodies were visualized by $\left[{ }^{14} \mathrm{C}\right]$ protein $\mathrm{A}$ and autoradiography. Lane I, total sample, without separation of immunoadsorbed 57 $\mathrm{kd}$; lane 2, supernatant after removal of protein A-Sepharose beads; lane 3, protein A-Sepharose beads with immunoadsorbed $57 \mathrm{kd}$. 


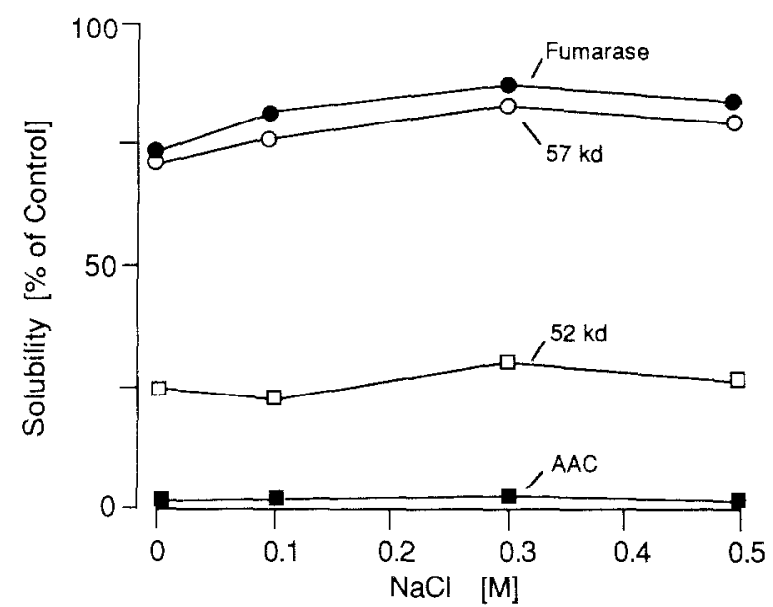

Figure 6. Extraction of $52 \mathrm{kd}$ and $57 \mathrm{kd}$ Polypeptides with Salt Isolated mitochondria were resuspended in SET buffer (see Experimental Procedures) containing $0-0.5 \mathrm{M} \mathrm{NaCl}$ at a protein concentration of $0.1 \mathrm{mg} / \mathrm{ml}$. PMSF and protease inhibitor of N. crassa (Schmidt et al., 1984) were added to final concentrations of $1 \mathrm{mM}$ and $0.1 \mathrm{mg} / \mathrm{ml}$, respectively. Samples were sonicated at $0^{\circ} \mathrm{C}-4^{\circ} \mathrm{C}$ three times for $1 \mathrm{~min}$ using a Branson sonifier with top-end microtip (setting 3, pulsed, $30 \%$ duty) and divided into halves. One half was kept on ice for determination of recoveries (total); the other half was centrifuged for $1 \mathrm{hr}$ at $165,000 \times \mathrm{g}$ to obtain a membrane and a supernatant fraction. Pellets were resuspended to the same volume as supernatants, and aliquots were taken from all samples for determination of fumarase activities. The rest of each sample was precipitated with TCA. Precipitates were solubilized in SDS-containing buffer, separated by electrophoresis, and then transferred to nitrocellulose paper. Immunodecoration was done with antibodies against $57 \mathrm{kd}$ and $52 \mathrm{kd}$ polypeptides as woll as ADP/ATP-carrier (AAC). Bound antibodies were visualized by $\left[{ }^{14} \mathrm{C}\right] \mathrm{pro}-$ tein $A$ and autoradiography. Autoradiographs were quantified by densitometry. Data are expressed as percentages of total immunoreactive protein and enzyme activities, respectively, recovered in the supernatants. Recoveries varied between $84 \%$ and $96 \%$.

activity was highly salt sensitive (Figure 7): $60 \mathrm{mM} \mathrm{NaCl}$ or $\mathrm{KCl}$ was sufficient to reduce the activity by $50 \%$. Removal of salt led to complete restoration of the activity (not shown).

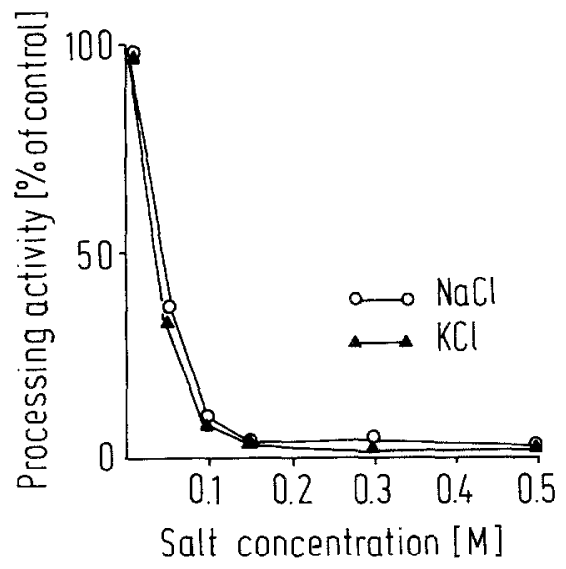

Figure 7. Salt Dependence of Processing Activity

Purified processing enzyme was assayed as described in Experimental Procedures, except that the test buffer was adjusted to different concentrations of either $\mathrm{NaCl}$ or $\mathrm{KCl}$. Activities are expressed relative to a control (no sait present).

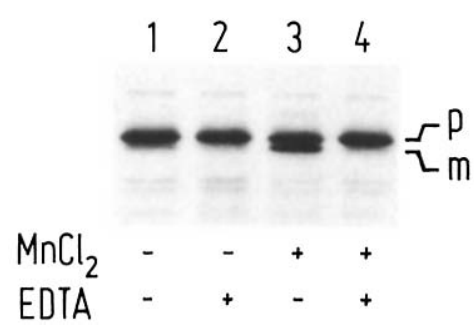

Figure 8. Inhibition of Processing Activity by EDTA

Purified processing enzyme was assayed under different conditions to demonstrate the metal dependence of the enzyme. Lane 1 shows the processing of the precursor of subunit 2 of $\mathrm{F}_{0} \mathrm{~F}_{1}$-ATPase without $\mathrm{Mn}^{2+}$ added. In lanes 2 and 4, $5 \mathrm{mM}$ EDTA was included during the test. in lanes 3 and 4, $2 \mathrm{mM} \mathrm{MnCl}_{2}$ was added. Incubation in each case was carried out with $0.15 \mathrm{U}$ of processing enzyme in a total volume of $200 \mu \mathrm{l}$.

The purified enzyme was metal dependent. Its activity was enhanced by adding manganese ions (Figure 8 , lane 3 vs. lane 1) or zinc or cobalt ions (not shown), and was inhibited by chelators such as EDTA (Figure 8, lanes 2 and 4 vs. lanes 1 and 3 ).

We investigated whether the purified enzyme cleaved the precursors of various proteins from the mitochondrial matrix, inner membrane, and intermembrane space. Indeed, it cleaved all the precursors we tested (Figure 9): Precursor to subunit 2 of ATPase was processed to the mature-sized form. The precursors of cytochrome $c_{1}$ and the Rieske Fe/S protein, which are cleaved in two steps (Teintze et al., 1982; Hartl et al., 1986), were processed to their respective intermediate-sized forms. ATPase subunit 9 , which was previously shown to be cleaved in two steps (Schmidt et al., 1984), was processed to the mature-sized form. Furthermore, the precursors of the following proteins (not shown in Figure 9) were found to be cleaved: yeast cytochrome $b_{2}$ to the intermediate form; and subunit 3 of ATPase, core proteins I and II of complex III, and isocitrate dehydrogenase to their mature forms. Thus it appears that the purified processing peptidase is responsible for the cleavage of a large number of mitochondrial precursor proteins. It may be the only enzyme that removes matrix-targeting signals.

To demonstrate that we have purified the authentic processing enzyme of mitochondria, we analyzed whether it cleaves at the correct processing site. The precursor to ATPase subunit 9 was translated in a reticulocyte lysate in the presence of ${ }^{35}$ S]methionine and incubated with the purified enzyme. The mature subunit 9 produced was immunoprecipitated and subjected to radiosequencing. Figure 10 shows that cleavage had occurred at the correct site.

\section{cDNA Cloning and Amino Acid Sequence of the $\mathbf{5 2}$ kd Polypeptide}

A full-length cDNA clone for the $52 \mathrm{kd}$ polypeptide (insert 108) was selected from a N. crassa cDNA library by antibody screening and colony hybridization (see Experimental Procedures). In vitro expression resulted in the synthesis of an authentic precursor of the $52 \mathrm{kd}$ polypeptide, as revealed by immunoprecipitation and size comparison to 


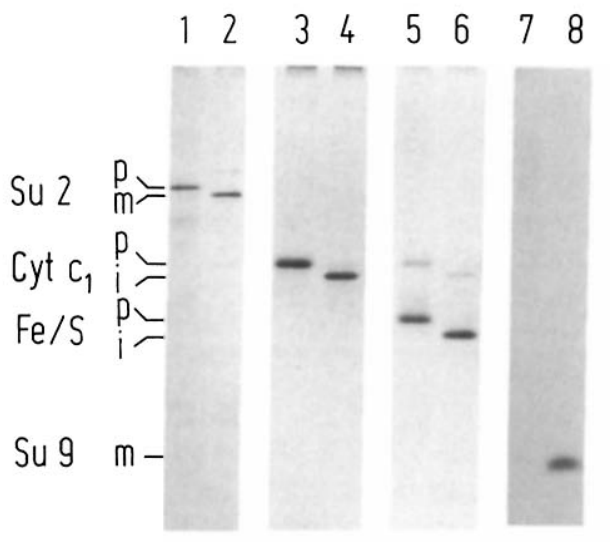

Figure 9. Processing of Different Mitochondrial Precursors by Purified Processing Enzyme

A reticulocyte lysate was programmed with Neurospora crassa poly $(A)^{+}$ mRNA and translated in the presence of $\left[{ }^{35}\right.$ S]methionine. The sample was divided into two halves. From one half the various mitochondrial precursor proteins were directly immunoprecipitated (odd lanes). The other half was incubated with the purified processing enzyme, and immunoprecipitation was then performed (even lanes). Lanes 1 and 2 contain ATPase subunit 2; lanes 3 and 4 contain cytochrome $c_{1}$; lanes 5 and 6 contain Rieske Fe/S protein; lanes 7 and 8 contain ATPase subunit 9 . The precursor ( $p$ ), intermediate (i), and mature $(m)$ forms of the proteins are labeled.

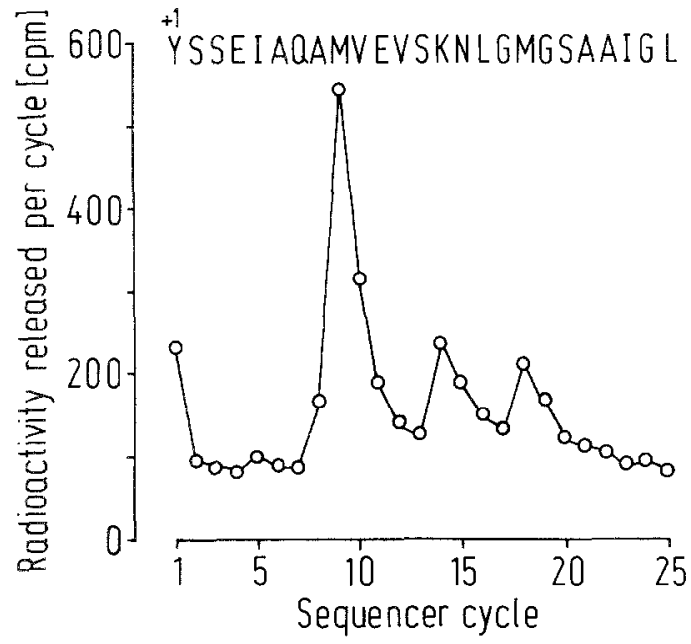

Figure 10. Radiosequencing of Mature ATPase Subunit 9 Produced by Cleavage of the $\left[{ }^{35}\right.$ S]Methionine-Labeled Precursor with Purified Processing Enzyme

The precursor of ATPase subunit 9 from Neurospora was synthesized in the presence of $\left[{ }^{35} \mathrm{~S}\right]$ methionine from the cloned cDNA by coupled transcription/translation in a reticulocyte lysate (Pfanner et al., 1987a). It was incubated with purilied processing enzyme and immunoprecipitated (see Experimental Procedures). The precipitate was subjected to electrophoresis; mature subunit 9 was eluted from the gel $(40,000 \mathrm{cpm})$ and subjected to 25 steps of solid-phase Edman degradation (Wachter et al., 1973). The amino acid sequence of Neurospora subunit 9 is shown (Viebrock et al., 1982); +1 marks the amino terminus of mature suburit 9 . Radioactivity is released with methionines at positions 9 and 18 , and with lysine at position 14 since subunit 9 is coupled via lysine residues to the solid phase (Schmidt et al., 1984).

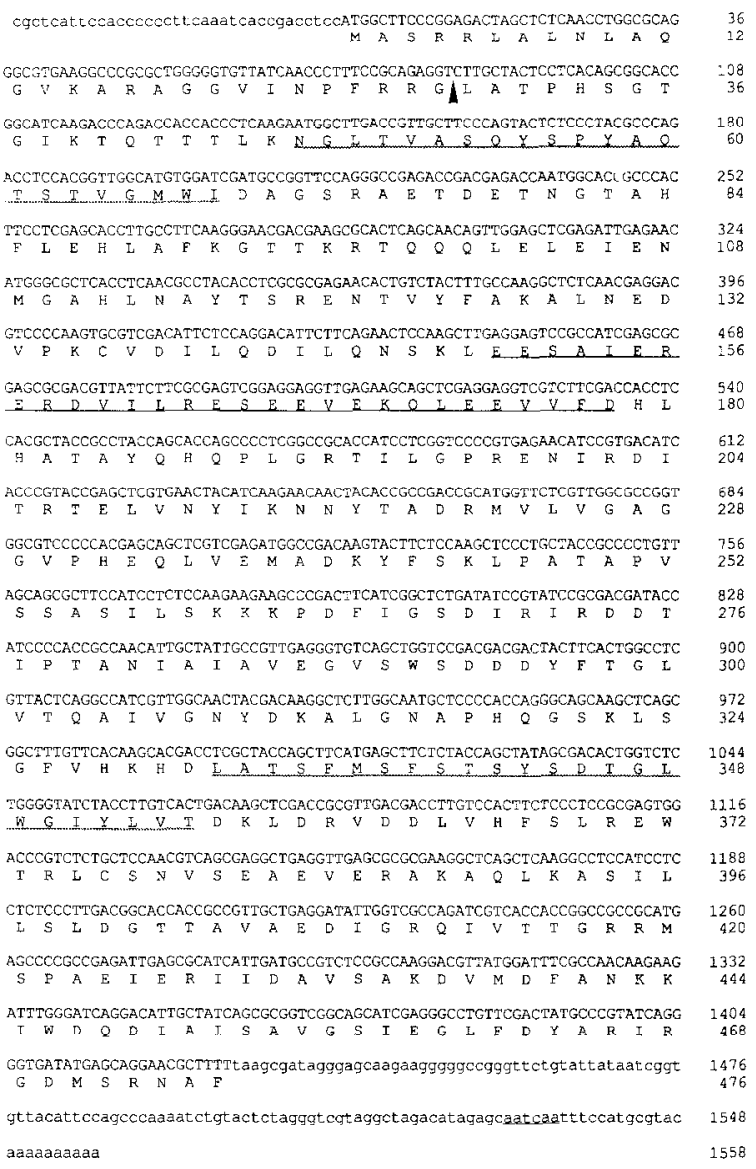

Figure 11. Nucleotide Sequence of the $52 \mathrm{kd}$ Protein cDNA and the Deduced Amino Acid Sequence

Nucleotides are numbered starting with the first nucleotide of the firs ATG triplet. Amino acids are given in the one-letter code. The proteolytic cleavage site of the processing peptidase is indicated by an arrowhead. The $\alpha$-helical segment with clustering of negatively charged residues is underline (residues 150-178). The stretches containing only uncharged amino acids are pointed out by dotted lines (residues 47-68 and 332-355, with Asp-345 as an exception). Untranslated regions are in lowercase letters. A putative polyadenylation signal (aatcaa) is underlined.

a $52 \mathrm{kd}$ precursor from a reticulocyle lysate programmed with poly $(A)^{+}$mRNA (not shown).

The nucleotide sequence of insert 108 and the deduced amino acid sequence of the precursor of $52 \mathrm{kd}$ polypeptide are given in Figure 11. The coding region of the $52 \mathrm{kd}$ cDNA contains 1428 nucleotides, corresponding to a precursor protein of 476 amino acid residues having a molecular mass of 52,483 daltons. The sequence of the amino terminus of the mature part of the protein was determined by gas-phase sequencing (Lottspeich, 1985) of isolated $52 \mathrm{kd}$ polypeptide (not shown). Threonine, proline, histidine, and serine were detected in positions 3-6, respectively, of the mature-sized protein. Amino acids in positions 1 and 2 could not be identified. Thus the presequence very likely consists of 28 amino acids. It containins 6 basic residues and no acidic residues. The carboxyl terminus of the presequence shows the motif Arg-Arg-Gly fol- 
lowed by leucine at position +1 of the mature part, which is similar to the cleavage sites found in a number of other mitochondrial precursor proteins (Schmidt et al., 1984; Hartl et al., 1986; Nicholson and Neupert, 1988). Indeed, the precursor of the $52 \mathrm{kd}$ polypeptide expressed in vitro could be processed to the mature-sized protein by the purified processing enzyme (not shown). Assuming that the precursor form is functionally inactive, the $52 \mathrm{kd}$ polypeptide therefore takes part in its own activation.

The mature protein is largely hydrophilic, with a net charge of -17 (at $\mathrm{pH} 7$ ). A continuous stretch of moderate hydrophobicity with more than 20 uncharged residues is found near the amino terminus (residues 47 to 68 ). Another hydrophobic region lies in the carboxy-terminal third of the polypeptide (residues 332 to 355 ), but is interrupted by a negative charge (aspartic acid) at position 345 . These regions are potential candidates for hydrophobic interaction of the $52 \mathrm{kd}$ polypeptide with the inner membrane. With regard to the distribution of charged amino acids, a clustering of 12 acidic residues, interspaced with 4 basic residues, over a stretch of 29 amino acids (residues 150 to 178) is notable. According to secondary structure prediction (Chou and Fasman, 1978), this region has the potential to form an $\alpha$-helical segment (residues 153 to 178). It might therefore be speculated that such a structural arrangement could be of functional importance for the interaction of the $52 \mathrm{kd}$ polypeptide with the positively charged presequences of imported precursor proteins.

\section{Discussion}

During past years a great deal of functional data on the import and assembly of mitochondrial proteins has been collected. We report here the identification of the first two components involved in this complex process.

What are the roles of the $57 \mathrm{kd}$ and $52 \mathrm{kd}$ polypeptides present in the purified preparation of the processing enzyme? Our observations suggest that the peptidase activity is associated with the $57 \mathrm{kd}$ polypeptide and that this component is the matrix processing peptidase (MPP) proper. In the absence of the $52 \mathrm{kd}$ polypeptide, MPP exhibits low but significant activity. In contrast, the $52 \mathrm{kd}$ component alone has no measurable enzyme activity. Because of its stimulating effect, we call the $52 \mathrm{kd}$ component the processing enhancing protein (PEP). PEP is present in large excess with respect to both its content in mitochondria and its activating effect on MPP. Preliminary results suggest that roughly equimolar amounts of PEP are sufficient for full activation.

If MPP performs the actual cleavage reaction, what is the function of PEP? A major task in understanding the mechanism of the processing peptidase is to explain how the enzyme can specifically act on so many different precursors, which differ vastly in the sequence of the cleavage sites and their position within the precursor molecules. Clearly, the information for the site of cleavage must lie in the protein sequence, since alterations of the presequences have been reported to lead to deficiencies in processing (Grivell, 1987; Hurt et al., 1987; Nguyen et al., 1987). For instance, deletion of amino acids 2 to 5 at the amino terminus of a fusion protein between the presequence of cytochrome oxidase subunit IV and mouse dihydrofolate reductase abolishes processing of the precursor by a mitochondrial extract but not targeting of the precursor to isolated mitochondria (Hurt et al., 1985). Our working hypothesis is that by the cooperation of two different proteins in the processing reaction, which may recognize different parts of the presequences, the reaction is greatly enhanced in rate and perhaps specificity. For example, one could imagine that PEP recognizes a certain general structural determinant of the presequences (e.g., amphipathic $\alpha$-helix or $\beta$-sheet) and, by binding to it, presents the precursor to the actual proteolytic component. With this assisting function, PEP might increase the catalytic rate and the specificity by a considerable factor. Indeed, we have never observed that the purified enzyme makes any fur ther proteolytic cleavage besides removing the presequence.

Besides its participation in the cleavage of presequences, PEP could have additional functions important for the transfer of proteins into mitochondria. PEP localized at the inner surface of the inner membrane could interact with the presequences of imported precursor proteins as soon as they enter the matrix space, thus playing a role in membrane translocation or preventing an unfavorable misfolding of the precursor. It is possible that the membrane-bound and soluble forms of PEP represent different functional states of the polypeptide.

Recently, temperature-sensitive mutations in Saccharomyces cereviseae were described that affect the processing of mitochondrial precursor proteins (Yaffe and Schatz, 1984; Yaffe et al., 1985). Two complementation groups were identified (mas-1 and mas-2) in which precursor proteins accumulated at the restrictive temperature. Matrix extracts from mas-1 cells have strongly reduced processing activity. An antibody prepared against a fusion protein between the amino-terminal fragment of the mas- 1 gene product and $\beta$-galactosidase specifically cross-reacted in Western biots with PEP of Neurospora mitochondrial extracts and with the purified processing enzyme. Furthermore, the protein sequence of PEP shows $60 \%$ homology to that of the mas-1 gene product (Witte et al., 1988). This observation suggests that mas-1 encodes the yeast equivalent to the Neurospora PEP. Interestingly, mas-1 cells at the nonpermissive temperature have been reported to accumulate precursors outside mitochondria (Yaffe and Schatz, 1984). This may support the idea of a role of PEP in the translocation of precursors into the mitochondria, as discussed above, in addition to its role in enhancing precursor processing.

The mitochondrial processing peptidase represents a new type of signal-cleaving enzyme that is different in almost all respects from other peptidases involved in protein translocation-in particular, the well-characterized bacterial leader peptidase (Zwizinski and Wickner, 1980; Wolfe et al., 1983) and the eukaryotic signal peptidase of the endoplasmic reticulum (Evans et al., 1986). The latter two enzymes are related with respect to their ability to correctly process both prokaryotic and eukaryotic signal sequences (Watts et al., 1983). Furthermore, both the leader 
peptidase and signal peptidase are membrane-integrated enzymes. Bacterial leader peptidase consists of a single integral membrane polypeptide, whereas the signal peptidase has been suggested to be present in a large membrane complex and may constitute part of a proteinaceous pore of the translocation apparatus (Evans et al., 1986). In contrast, the mitochondrial processing enzyme is not inlegrated in the membrane, and it does not cleave precursors of secreted proteins. Also, in contrast to leader and signal peptidase, it is a metal-dependent enzyme. Finally, two polypeptides are required for activity, and these are present as monomers and do not form a stoichiometric complex.

Thus the mitochondrial MPP appears to represent a member of a new class of processing enzymes. The corresponding enzyme in the chloroplast stroma may also belong to this new class. It is not particularly surprising that in organelles such as mitochondria and chloroplasts, the processing enzymes are not related to those cleaving secreted precursors. The general mechanisms and pathways of importing precursor proteins into organelles bounded by a double membrane are grossly different from the translocation of precursors across the bacterial plasma membrane or across the membrane of the endoplasmic reticulum. In earlier studies on the complex sorting pathways of precursors into the mitochondrial intermembrane space, we have described that this process involves complete transfer into the matrix and retranslocation across the inner membrane (Hartl et al., 1987). It is tempting to propose that the processing enzyme(s) participating in the latter step, namely, cleavage of the second part of the presequence from the respective precursors, bears evolutionary relationships to the bacterial leader peptidase.

\section{Experimental Proceaures}

Growth of Neurospora and Preparation of Mitochondria

N. crassa wild-type strain 74A was grown for $15 \mathrm{hr}$ as described by Korb and Neupert (1978). Cells were harvested by filtration. Storage at $-20^{\circ} \mathrm{C}$ for several months did not lead to loss of processing peptidase activity. Mitochondria were isolated as published (Korb and Neupert, 1978) in SET buffer (0.25 M sucrose, $1 \mathrm{mM}$ EDTA, $30 \mathrm{mM}$ Tris-HCl [pH 7.5]) containing $1 \mathrm{mM}$ PMSF. They were washed once in the same buffer without EDTA, sedimented by centrifugation for $15 \mathrm{~min}$ at 14,000 $\times \mathrm{g}$, and stored at $-20^{\circ} \mathrm{C}$.

\section{Purification of the Processing Enzyme}

All the following steps were carried out at $1^{\circ} \mathrm{C}$. A preparation routinely started with $200 \mathrm{~g}$ of frozen cells.

\section{Preparation of a Total Extract}

Neurospora hyphae were resuspended in $1200 \mathrm{ml}$ of isolation buffer (30 mM Tris [pH 8.2], $0.1 \mathrm{mM}$ PMSF) using a Waring blender. The cells were then broken by passing them three times through a grind mill (Sebald et al., 1979). Cellular debris and unbroken cells were removed by centrifugation for $2 \mathrm{hr}$ at $17,700 \times \mathrm{g}$. The resulting supernatant was adjusted to $\mathrm{pH} 7.5$ with concentrated $\mathrm{HCl}$. It was referred to as total exIract.

\section{DEAE-Cellulose Chromatography}

The total extract was loaded onto a DE-52 column (Whatman) $(2.5 \times 35$ $\mathrm{cm}$ ) equilibrated with $10 \mathrm{mM}$ Tris- $\mathrm{HCl}(\mathrm{pH} 7.5)$. After washing with 1.4 I of equilibration buffer proteins were eluted with 1.7 I of a salt gradient from 0 to $300 \mathrm{mM} \mathrm{NaCl}$ in equilibration buffer (flow rate $3.3 \mathrm{ml} / \mathrm{min}$ ) The processing activities of different fractions were determined according to the standard processing peptidase assay. The active fractions, which eluted at $200 \mathrm{mM} \mathrm{NaCl}$, were pooled.

\section{Zn-Chelate Chromatography}

Metal-chelate-affinity Sepharose 6B (Pharmacia) $(100 \mathrm{ml}$ ) was loaded with $\mathrm{Zn}^{2+}$ ions to saturation. The column $(2.5 \times 20 \mathrm{~cm})$ was equilibrated with $30 \mathrm{mM}$ Tris- $\mathrm{PO}_{4}(\mathrm{pH} 7.0), 200 \mathrm{mM} \mathrm{NaCl}$. The pooled activity from the previous column was loaded. Washing was done with $800 \mathrm{ml}$ of equilibration buffer. Elution was carried out with a linear gradient (1 I) from 0 to $30 \mathrm{mM}$ histidine in equilibration buffer (flow rate 2.5 $\mathrm{ml} / \mathrm{min}$ ). Active fractions were pooled.

PEI.Cellulose Chromatography

$P E$-cellulose (Sigma) $(2.5 \times 10 \mathrm{~cm})$ was equilibrated with $10 \mathrm{mM}$ Tris- $-\mathrm{PO}_{4}(\mathrm{pH} 7.0), 100 \mathrm{mM} \mathrm{NaCl}$. The processing peptidase pool of the $\mathrm{Zn}$-chelate affinity eluate was diluted 2-fold with $\mathrm{H}_{2} \mathrm{O}$ and applied to PEI-cellulose. Ihe column was washed with $250 \mathrm{mi}$ of equilibration buffer and eluted with a $500 \mathrm{ml}$ gradient from 10 to $100 \mathrm{mM}$ Tris-PO $(\mathrm{pH} 7.0), 100 \mathrm{mM} \mathrm{NaCl}$ (flow rate $2.5 \mathrm{ml} / \mathrm{min}$ ). Aliquots were taken for determination of processing peptidase activity, and the remaining fractions were immediately subjected to precipitation with PEG.

\section{PEG Precipitation}

PEG precipitation was performed according to Ingham (1984). A stock solution of $28 \%$ (wt/vol) of PEG 8000 (Sigma) in $\mathrm{H}_{2} \mathrm{O}$ was prepared. To each of the eluted fractions of the PEI-column an equal volume of the PEG stock solution was slowly added and gently stirred overnight. Active fractions were pooled and centrifuged for $20 \mathrm{~min}$ at $16,000 \times$ $g$. The pellet was washed once with 14\% PEG arid resuspended in 10 $\mathrm{ml}$ of $10 \mathrm{mM}$ Tris- $\mathrm{HCl}(\mathrm{pH} 7.5), 1 \%$ Triton X-100.

\section{Ecteola-Cellulose Chromatography}

The resuspended pellet was adjusted to $300 \mathrm{mM} \mathrm{NaCl}$ by adding solid $\mathrm{NaCl}$. After stirring for $30 \mathrm{~min}$, virtually all of the protein was resolubilized. The solution was cleared by centrifugation for $10 \mathrm{~min}$ at 16,000 $x \mathrm{~g}$ and the supernatant was diluted with $30 \mathrm{mM}$ Tris- $\mathrm{PO}_{4}(\mathrm{pH} 7.0)$, $1 \%$ Triton X-100 to a final $\mathrm{NaCl}$ concentration of $75 \mathrm{mM}$ (volume $40 \mathrm{ml}$ ). It was then loaded onto a column of Ecteola-cellulose (Sigma) ( $0.6 \times$ $7.0 \mathrm{~cm}$ ) equilibrated with $10 \mathrm{mM}$ Tris- $\mathrm{PO}_{4}(\mathrm{pH} 7.0), 75 \mathrm{mM} \mathrm{NaCl}, 1 \%$ Triton X-100. After washing with $15 \mathrm{ml}$ of the same buffer, processing activity was eluted with a linear salt gradient from 75 to $300 \mathrm{mM} \mathrm{NaCl}$ in equilibration buffer (flow rate $0.17 \mathrm{~m} / / \mathrm{min}$ ). All eluted fractions were precipitated with PEG by adding an equal volume of a $40 \%$ stock solution and gently mixing end over end for $24 \mathrm{hr}$. Precipitates were resolubilized in $10 \mathrm{mM}$ Tris ( $\mathrm{pH} 7.5$ ). Active fractions were pooled and stored at $-20^{\circ} \mathrm{C}$. To obtain purified $52 \mathrm{kd}$ polypeptide, fractions eluting at a salt concentration of 100-120 mM were pooled and PEG-precipitated as described above. These fractions were inactive in the processing assay and contained only $52 \mathrm{kd}$ polypeptide as revealed by SDS-polyacrylamide gel electrophoresis and Western blotting.

\section{Superose 12 Gel Chromatography}

FPLC gel chromatography was performed on a Superose 12 column (Pharmacia) equilibrated with $10 \mathrm{mM}$ Tris- $\mathrm{HCl}(\mathrm{pH} 7.5), 200 \mathrm{mM} \mathrm{NaCl}$. The eluate of $\mathrm{Zn}$-chelate chromatography $(0.5 \mathrm{mil})$ containing $0.8 \mathrm{mg}$ of protein was injected. The column was developed at a flow rate of 0.5 $\mathrm{ml} / \mathrm{min}$. No processing activity appeared in the first $12 \mathrm{ml}$ of eluate. Fractions of $0.25 \mathrm{ml}$ were collected and stored at $-20^{\circ} \mathrm{C}$.

\section{Preparation of Specific Antisera}

Antisera were raised in rabbits according to Knudsen (1985), with some modifications. Purified processing enzyme from a routine preparation was electrophoresed on an SDS-polyacrylamide gel and blotted to nitrocellulose paper (Burnette, 1981). The $52 \mathrm{kd}$ and $57 \mathrm{kd}$ polypeptides were stained with Ponceau $S$, and the bands were cull out and dried. After solubilization of the nitrocellulose-bound proteins in dimethyl sulfoxide $(0.3 \mathrm{ml})$ and addition of an equal volume of Freund's complete adjuvant (first injection) or incomplete adjuvant (all subsequent injections), the mixture was injected subcutaneously in the neck region twice at biweekly intervals. One month after the second injection the rabbits were bled, and the presence of antibodies was checked by Western blotting. Immunoglobulins were prepared by ammonium sulfate precipitation followed by DEAE-cellulose chromatography (Deutsch, 1967; Fahey, 1967)

\section{Synthesis of Precursor Proteins}

Cell-free synthesis of N. crassa precursor proteins in rabbit reticulocyte Iysates (Pelham and Jackson, 1976) was carrled out as descrlbed before using either poly(A) ${ }^{+}$mRNA (Schleyer et al., 1982) or mRNA produced by in vitro transcription from cDNA cloned into transcription 
vectors (Pfanner et al., 1987a; Hartl et al., 1987; Kleene et al., 1987). Desalting of postribosomal supernatants was performed by gel filtration using PD-10 columns (Pharmacia).

\section{Processing Peptidase Assay}

One hundred microliters of desalted lysate containing radiolabeled $N$. crassa precursor proteins was mixed with the processing en<yme Iraction to be tested. When necessary, $30 \mathrm{mM}$ Tris $-\mathrm{HCl}(\mathrm{pH}$ 8.2) was added to keep the $\mathrm{NaCl}$ concentration in the final assay below $30 \mathrm{mM}$. Ten microliters of $10 \%$ Triton $X-100,1 \mu$ of $0.1 \mathrm{M}$ PMSF (in ethanol), and $2 \mu \mathrm{l}$ of $0.1 \mathrm{M} \mathrm{MnCl}_{2}$ were added to a $100 \mu \mathrm{l}$ assay, and incubation was carried out for $60 \mathrm{~min}$ at $25^{\circ} \mathrm{C}$. In cases where the enzyme was bound to protein A-Sepharose via specific antibodies, all samples were shaken end over end during incubation. The processing reaction was stopped by addition of $\mathrm{NaCl}$ and EDTA from 10-fold concentrated stock solutions to final coricentrations of $300 \mathrm{mM}$ and $5 \mathrm{mM}$, respectively Processing products were analyzed by immunoprecipitation (Schleyer and Neupert, 1985), SDS-polyacrylamide gel electrophoresis, and fluorography.

One unit of enzyme activity is defined as the amount of enzyme that processes $1 \mathrm{fmol} / \mathrm{min}$ of the precursor of ATPase subunit 2 under the conditions described above.

Quantification of the Amount of Precursor of ATPase Subunit 2 Synthesized in Reticulocyte Lysates

Proteins were synthesized in rabbit reticulocyte lysates in the presence of $\mathrm{N}$. crassa poly $(\mathrm{A})^{+} \mathrm{mRNA}$, and radiolabeled with $\left[^{35} \mathrm{~S}\right]$ mothionine as described above. The precursor of ATPase subunit 2 was quantitatively immunoprecipitated from each lysate used and subjected to SDS-polyacrylamide yel eleclrophoresis and fluorography. The radioactive bands of three parallel precipitations were cut out, and the radioactivity was determined according to Bonner (1983). Based on the specitic radioactivity of methionine in the lysate and the number of methionines in precursor of ATPase subunit 2, the concentration of precursor was calculated to be $57 \mathrm{pM}$, with only slight variation between different lysates.

\section{cDNA Cloning and DNA Sequencing}

Antibody screening of a $\mathrm{N}$. crassa cDNA library (Kleene et al., 1987) in $\mathrm{pEX}$ vectors for $52 \mathrm{kd}$ polypeptide clones was performed according to Stanley and Luzio (1984). One short CDNA insert, which was also positive in hybrid selection (Viebrock et al., 1982) of $52 \mathrm{kd} \mathrm{mRNA,} \mathrm{was}$ used to screen a N. crassa cDNA library in pBR322 by colony hybrid ization. Two positive clones were obtained (inserts 107 and 108; length of the inserts ca. $1.6 \mathrm{~kb}$ ). For in vitro expression, cDNA insert 108 was cut with $\mathrm{Ncol}$ (deleting the entire 5 ' noncoding region including the $\mathrm{dG}$ $\mathrm{dC}$ tails introduced by the cDNA cloning procerdure) and cloned into transcription vector pGEM3 (Promega) (Stuart et al., 1987). For supercoil sequencing (Chen and Seeburg, 1985), full-length cDNA insert 108 was cloncd into pUC19 in both orientations and shortened by the Exolll method (Henikoff, 1984). Parts of the cDNA clones and of genomic $52 \mathrm{kd}$ clones were also sequenced using $52 \mathrm{kd}$-specific DNA primers.

\section{Miscellaneous}

Fractionation by sonication and alkaline treatment of mitochondria were carried out exactly as described previously (Hartl et al., 1987; Fujiki et al., 1982; Pfanner et al., 1987b). TCA precipitation of proteins and determination of protein concentration were performed according to published procedures (Bradford, 1976; Bensadoun and Weinstein, 1976). SDS-polyacrylamide gel electrophoresis was performed as described by Laemmli (1970). For fiuorography, gels were incubated for $30 \mathrm{~min}$ in Amplify (Amersham) and were exposed to Kodak X-Omat AR films at $-80^{\circ} \mathrm{C}$. Metabolically labeled mitochondria were isolated from cells grown in the presence of $\left[{ }^{35} \mathrm{~S}\right]$ sulfate or $\left[{ }^{3} \mathrm{H}\right]$ leucine (Korb and Neupert, 1978; Hartl et al., 1986)

\section{Acknowledgments}

We thank Dr. E. Wachter for performing the radiosequencing experiments, Dr. F. Lottspeich and C. Eckerskorn for gas-phase sequencing, and Dr. W. Wickner for many critical suggestions during the preparation of the manuscript. We are grateful to $\mathrm{H}$. Müller for producing the
pSP6-based clone of ATPase subunit 9 cDNA, to M. Braun, S. Meier I. Kohl, and $G$. Ludwig for expert technical assistance, and to Dr. D. Nicholson for help in editing the manuscript. We also thank Dr. $\mathrm{R}$ Mertz for supplying oligonucleotides. This work was supported by the Deutsche Forschungsgemeinschaft (SFB 184), by the Genzentrum München, and by the Fonds der Chemischen Industrie.

The costs of publication of this article were defrayed in part by the payment of page charges. This article must therefore be hereby marked "advertisement" in accordance with 18 U.S.C. Section 1734 solely to indicate this fact

Received November 5, 1987; revised February 16, 1988

\section{References}

Bensadoun, A., and Weinstein, D. (1976). Assay of proteins in the presence of interfering materials. Anal. Biochem. 70, 241-250.

Böhni, P., Gasser, S., Leaver, C., and Schatz, G. (1980). A matrixlocalized mitochondrial protease processing cytoplasmically made precursors to mitochondrial proteins. In The Organization and Expression of the Mitochondrial Genome, A. M. Kroon and C. Saccone, eds. (Amsterdam: Elsevier/North-Holland), pp. 423-433.

Böhni, P., Daum, G., and Schatz, G. (1983). Import of proteins into mitochondria: partial purification of a matrix-localized protease involved in cleavage of mitochondrial precursor polypeptides. J. Biol. Chem. $258,4937-4943$.

Bonner, W. M. (1983). Use of fluorography for sensitive isotope detection in polyacrylamide gels and related techniques. Meth. Enzymol. 96 215-222.

Bradford, M. M. (1976). A rapid and sensitive method for the quantita tion of microgram quantities of protein utilizing the principle of protein dye binding. Anal. Biochem. 72, 248-254.

Burnette, W. N. (1981). "Western blotting": electrophoretic transfer of proteins from sodium dodecyl sulfate-polyacrylamide gels to unmodified nitrocellulose and radiographic detection with antibody and radioiodinated protein A. Anal. Biochem. 112, 195-203.

Chen, E. J., and Seeburg, P. H. (1985). Supercoil sequencing: a fast and simple method for sequencing plasmid DNA. DNA 4, 165-170. Chou, P. W., and Fasman, G. D. (1978). Empirical prediction of protein conformation. Annu. Rev. Biochem. 47, 251-276.

Conboy, J. G., Fenton, W. A., and Rosenberg, L. E. (1982). Processing of pre-ornithine transcarbamylase requires a zinc-dependent protease localized to the mitochondrial matrix. Biochem. Biophys. Res. Commun. 105, 1-7.

Deutsch, H. F., (1967). Preparation of immunoglobulin concentrates. In Methods in Immunology and Immunochemistry, Vol. 1, C. A. Williams and M. W. Chase, eds. (New York: Academic Press), pp. 315-321.

Dev, J. K., and Ray, P. H. (1984). Rapid assay and purification of a unique signal peptidase that processes the prolipoprotein from Escherichia coli B. J. Biol. Chem. 259, 11114-11120

Emr, S. D., Vassarotti, A., Garrett, J., Geller, B. L., Takeda, M., and Douglas, M. G. (1986). The amino terminus of the yeast $F_{1}$-ATPase $\beta$-subunit precursor functions as a mitochondrial import signal. J. Cell. Biol. 102, 523-533.

Evans, E. A., Gilmore, R, and Blobel, G. (1986). Purification of microsomal signal peptidase as a complex. Proc. Natl. Acad. Sci. USA 83, 581-585

Fahey, J. L. (1967). Chromatographic separation of immunoglobulins. In Methods in Immunology and Immunochemistry, Vol. 1, C. A. Wit liams and M.W. Chase, eds. (New York: Academic Press), pp. 321-332.

Fujiki, Y., Hubbard, A. L., Fowler, S., and Lazarow, P. B. (1982). Isolation of intracellular membranes by means of sodium carbonate treatment: application to endopiasmic reticulum. J. Cell Biol. 93, 97-102. Grivell, L. A. (1987). Protein import into mitochondria. Int. Rev. Cytol., in press.

Grivell, L. A., van der Veen, R., Kwakman, J., Oudshoorn, P., dild Meijer. M. (1987). Mitochondrial biogenesis: recent development and insights. Phil. Trans. Royal Soc., in press. 
Hartl, F.-U. Schmidt, B., Wachter, E., Weiss, H., and Neupert, W. (1986). Transport into mitochondria and intramitochondrial sorting of the $\mathrm{Fe} / \mathrm{S}$ protein of ubiquinol-cytochrome $\mathrm{c}$ reductase. Cell $47,939-$ 951.

Hartl, F.-U., Ostermann, J., Guiard, B., and Neupert, W. (1987). Successive translocation into and out of the mitochondrial matrix: targeting of proteins to the intermembrane space by a bipartite signal peptide. Cell 51, 1027-1037.

Henikoff, S. (1984). Unidirectional digestion with exonuclease III creates breakpoints for DNA sequencing. Gene 28, 351-359.

Horwich, A. L., Kalousek, F., Mellman, I, and Rosenberg, L. E. (1985). A leader peptide is sufficient to direct mitochondrial import of a chimeric protein. EMBO J. 4, 1129-1135.

Horwich, A. L., Kalousek, F., Fenton, W. A, Pollock, R. A., and Rosenberg, L. E. (1986). Targeting of pre-ornithine transcarbamylase to mitochondria: definition of critical regions and residues in the leader peptide. Cell 44, 451-459.

Hurt, E. C., Pesold-Hurt, B., and Schatz, G. (1984). The cleavable prepiece of an imported mitochondrial protein is sufficient to direct cytosolic dihydrofolate reductase into the mitochondrial matrix. FEBS Lett. 178, 306-310.

Hurt, E. C., Pesold-Hurt, B., Suda, K., Oppliger, W., and Schatz, G. (1985). The first twelve amino acids (less than half of the pre-sequence) of an imported mitochondrial protein can direct mouse cytosolic dihydrofolate reductase into the yeast mitochondrial matrix. EMBO J. 4, 2061-2068.

Hurt, C. H., Allison, O. S., Müller, U., and Schatz, G. (1987). Aminoterminal deletions in the presequence of an imported mitochondrial protein block the targeting function and proteolytic cleavage of the presequence at the carboxy terminus. J. Biol. Chem. 262, 1420-1424. Ingham, K. C. (1984). Protein precipitation with polyethylene glycol. Meth. Enzymol. 104, 351-356.

Keng, T., Alani, E., and Guarente, L. (1986). The nine amino-terminal residues of $\delta$-aminolevulinate synthase direct $\beta$-galactosidase into the mitochondrial matrix. Mol. Cell. Biol. 6, 355-364.

Kleene, R., Pfanner, N., Pfaller, R., Link, T. A., Sebald, W., Neupert, W., and Tropschug. M. (1987). Mitochondrial porin of Neurospora crassa: cDNA cloning, in vitro expression and import into mitochondria. EMBO J. 6, 2627-2633.

Knudsen, K. A. (1985). Proteins transferred to nitrocellulose for use as immunogens. Anal. Biochem. 147, 285-288.

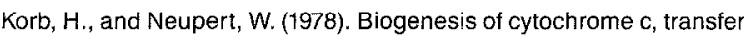
to mitochondria and conversion to holocytochrome c. Eur. J. Biochem. 91, 609-620.

Kumamoto, T. Ito, A., and Omura, T. (1986). Characterization of a mitochondrial matrix protease catalyzing the processing of adrenodoxin precursor. J. Biochem. 100, 247-254.

Laemmli, U. K. (1970). Cleavage of structural proteins during the assembly of the head of bacteriophage T4. Nature 227, 680-685.

Lewin, A. S., and Norman, D. K. (1983). Assembly of $F_{1}$-ATPase in isolated mitochondria. J. Biol. Chem. 258, 6750-6755.

Lottspeich, F. (1985). High performance liquid chromatography in microsequencing. Trends Anal. Chem. 4, 244-246.

McAda, P. C., and Douglas, M. G. (1982). A neutral metalloendoprotease involved in the processing of an $F_{1}$-ATPase subunit precursor in mitochondria. J. Biol. Chem. 257, 3177-3182.

Miura, S., Mori, M., Amaya, Y., and Tatibana, M. (1982). A mitochondrial protease that cleaves the precursor of ornithine carbamoyl transferase. Eur. J. Biochem. 122, 641-647.

Nguyen, M., Argan, C., Sheffield, W. P., Bell, A. W., Shields, D., and Shore, G. C. (1987). A signal sequence domain essential for processing, but not import, of mitochondrial pre-ornithine carbamyl transferase. J. Cell Biol. 104, 1193-1198.

Nicholson, D., and Neupert, W. (1988). Synthesis and assembly of mitochondrial proteins. In Protein Transfer and Organelle Biogenesis, R. C. Das and P. W. Robins, eds. (New York: Academic Press), in press.

Ou, W., Ho, A., Morohushi, K., Fuji-Kuriyama, L., and Omura, T. (1986).
Processing-independent in vitro translocation of cytochrome p-450 (scc) precursor across mitochondrial membranes. J. Biochem. 100, 1287-1296.

Pelham, H. R. B., and Jackson, R. J. (1976). An efficient mRNA dependent translation system from reticulocyte lysates. Eur. J. Biochem. 67, 247-256.

Pfanner, N., and Neupert, W. (1987). Biogenesis of mitochondrial energy transducing complexes. In Current Topics in Bioenergetics, Vol. 15, C. P. Lee, ed. (New York: Academic Press), pp. 177-219.

Pfanner, N., Tropschug, M., and Neupert, W. (1987a). Mitochondrial protein import: nucleoside triphosphates are involved in conferring import-competence to precursors. Cell 19, 815-823.

Pfanner, N., Hartl, F.-U., Guiard, B., and Neupert, W. (1987b). Mitochondrial precursor proteins are imported through a hydrophilic membrane environment. Eur. J. Biochem. 769, 289-293.

Robinson, C., and Ellis, R. J. (1984). Transport of proteins into chloroplasts: partial purification of a chloroplast protease involved in the processing of imported precursor polypeptides. Eur. J. Biochem. 142 337-342.

Roise, D., Horvath, S. J., Tomich, J. M., Richards, J. H., and Schatz, G. (1986). A chemically synthesized pre-sequence of an imported mitochondrial protein can form an amphiphilic helix and perturb natura and artificial phospholipid bilayers. EMBO J. 5, 1327-1334.

Sagara, Y., Ito, A., and Omura, T. (1984). Partial purification of a metalloprotease catalyzing the processing of adrenodoxin precursor in bovine adrenal cortex mitochondria. J. Biochem. 96, 1743-1752.

Schleyer, M., and Neupert, W. (1985). Transport of proteins into mitochondria: translocationa! intermediates spanning contact sites between outer and inner membranes. Cell 43, 339-350.

Schleyer, M., Schmidt, B., and Neupert, W. (1982). Requirement of a membrane potential for the posttranslational transfer of proteins into mitochondria. Eur. J. Biochem. 125, 109-116

Schmidt, B., Wachter, E., Sebald, W., and Neupert, W. (1984). Processing peptidase of Neurospora mitochondria. Two-step cleavage of im ported ATPase subunit 9. Eur. J. Biochem. 144, 581-588.

Sebald, W. Neupert. W. and Weiss. H. (1979). Preparation of Neu rospora mitochondria. Meth. Enzymol. 55F, 144-148.

Stanley, K. K., and Luzio, J. P. (1984). Construction of a new family of high efficiency bacterial expression vectors. Identification of cDNA clones coding for human liver proteins. EMBO J. 3, 1429-1434.

Stuart, R. A., Neupert, W., and Tropschuc, M. (1987). Deficiency in mRNA splicing in a cytochrome $c$ mutant of Neurospora crassa: importance of carboxy terminus for import of apocytochrome $c$ into mitochondria. EMBO J. 6, 2131-2137.

Teintze, M., Slaughter, M., Weiss, H., and Neupert, W. (1982). Biogenesis of mitochondrial ubiquinol: cytochrome $\mathrm{c}$ reductase (cytochrome $b c_{1}$ complex). J. Biol. Chem. 257, 10364-10371.

Vassarotti, A., Chen, W.-J., Smagula, C., and Douglas, M. G. (1987a) Sequences distal to the mitochondrial targeting sequences are necessary for the maluralion of the $F_{1}$-ATPase $\beta$-subunit precursor in mitochondria. J. Biol. Chem. 262, 411-418.

Vassarotti, A., Stroud, R., and Douglas, M. G. (1987b). Independent mutations at the amino terminus of a protein act as surrogate signals for mitochondrial import. EMBO J. 6, 705-711.

Viebrock, A., Perz, A., and Sebald, W. (1982). The imported preprotein of the proteolipid subunit of the mitochondrial ATP synthase from Neurospora crassa. Molecular cloning and sequencing of the mRNA EMBO J. 1, 565-571.

von Heijne, G. (1986). Mitochondrial targeting sequences may form amphiphilic helices. EMBO J. 5, 1335-1342.

Wachter, E., Machleidt, W., Hofner, H., and Otto, J. (1973). Aminopropy glass and its p-phenylene diisothiocyanate derivatives, a new support in solid-phase Edman degradation of peptides and proteins. FEBS Lett. 35, 97-102.

Watts, C., Wickner, W., and Zimmermann, R. (1983). M13 procoat and a pre-immunoglobulin share processing speciticity but use different membrane receptor mechanisms. Proc. Natl. Acad. Sci. USA 80, $2809-2813$ 
Witte, C., Jensen, R. E., Yaffe, M. R., and Schatz, G. (1988). MAS1, a gene essential for yeast mitochondrial assembly, encodes a subunit of the mitochondrial processing protease. EMBO J. 7, 1439-1447.

Wolfe, P. B. Wickner, W., and Goodman, J. M. (1983). Sequence of the leader peptidase gene of Escherichia coli and the orientation of leader peptidase in the bacterial envelope. J. Biol. Chem. 258, 12073-12080. Yaffe, M. P., and Schatz, G. (1984). Two nuclear mutations that block mitochondrial protein import in yeast. Proc. Natl. Acad. Sci. USA 81, $4819-4823$

Yaffe, M. P., Ohta, S., and Schatz, G. (1985). A yeast mutant temperature-sensitive for mitochondrial assembly is deficient in a mitochondrial protcase activity that clcaves imported precursor polypep tides. EMBO J. 4, 2069-2074.

Zwizinski, C., and Neupert, W. (1983). Precursor proteins are transported into mitochondria in the absence of proteolytic cleavage of the additional sequences. J. Biol. Chem. 258, 13340-13346.

Zwizinski, C., and Wickner, W. (1980). Purification and characterisation of leader (signal) peptidase from Escherichia coli. J. Biol. Chem. 255, $7973-7977$ 